\title{
The Productivity of Duck in Different Temperature Cage Management
}

\section{Produktivitas Itik Lokal pada Manajemen Pemeliharaan Perbedaan Suhu Kandang}

\author{
Tertia Delia Nova*, Erman Syahruddin, dan Rijal Zein \\ Fakultas Peternakan Universitas Andalas, Padang, Sumatera Barat \\ Email: tertia16unand@gmail.com
}

\begin{abstract}
This study aims to determine the performance of ducks on the effect of differences in cage temperature. This study used 545 -week-old male ducks selected from 66 ducks. The research method used was randomized block design (RBD). The treatment used is the regulation of the temperature of the cage which is divided into three temperature levels, namely: A (cold temperature), $\mathrm{B}$ (room temperature), and C (hot temperature). The observed variables were duck performance in the form of feed consumption, body weight gain and feed conversion. The results of this study indicate that the difference in temperature of the cage became a very significant $(\mathrm{P}<0.01)$ on the consumption of rations, weight gain and conversion. The results of the study concluded that the maintenance of ducks at three different cage temperatures had a very significant $(\mathrm{P}<0.01)$ on feed consumption and body weight gain, but had no effect on feed conversion. The best results were found in the temperature of the cold cage with the consumption of rations of $2964.33 \mathrm{~g} / \mathrm{head}$, which resulted in body weight of $711.83 \mathrm{~g} / \mathrm{head}$ of $\mathrm{g} / \mathrm{head}$, and conversion of 4.2 . While the body weight of 1437 percentage of carcass was $67.64 \%$ in the study. The highest yield IOFC results (income over feed cost) cage in cold temperatures with a profit of Rp. 3,375.15/head. The maintenance of ducks at three different cage temperatures had no significant effect $(\mathrm{P}>0.05)$ on the weight of the spleen, thyroid and kidney and the work of the spleen, thyroid and kidney organs was still normal
\end{abstract}

Keywords: bodyweight gain, cage temperature, consumption, conversion, duck.

\begin{abstract}
ABSTRAK
Penelitian ini bertujuan untuk mengetahui performa itik terhadap pengaruh perbedaan suhu kandang. Penelitian ini menggunakan 54 ekor itik jantan berumur 5 minggu yang diseleksi dari 66 ekor itik. Metode penelitian yang digunakan yaitu Rancangan Acak Kelompok (RAK). Perlakuan yang digunakan ialah pengaturan suhu kandang yang dibagi atas tiga tingkatan suhu, yaitu: A (suhu dingin), B (suhu ruang), dan $\mathrm{C}$ (suhu panas). Peubah yang diamati ialah performa itik berupa konsumsi ransum, pertambahan bobot badan dan konversi ransum. Hasil penelitian ini menunjukkan bahwa perbedaan suhu kandang memberikan pengaruh berbeda sangat nyata $(\mathrm{P}<0,01)$ terhadap konsumsi ransum, pertambahan bobot badan dan konversi ransum. Berdasarkan hasil penelitian yang telah dilakukan dapat disimpulkan bahwa pemeliharaan itik Lokal pada tiga suhu kandang yang berbeda, berpengaruh sangat nyata $(\mathrm{P}<0,01)$ terhadap konsumsi ransum dan pertambahan bobot badan, namun tidak berpengaruh terhadap konversi ransum. Hasil terbaik terdapat pada suhu kandang dingin dengan konsumsi ransum sebesar 2964,33 g/ekor, bobot hidup sebesar 1437 g/ekor, dan konversi ransum 4,22. Sedangkan persentase karkas $67,64 \%$ yang menghasilkan bobot badan sebesar 711,83 g/ekor selama penelitian. Hasil IOFC (income over feed cost) hasil yang paling tinggi kandang pada suhu dingin dengan keuntungan sebesar Rp. 3.375,15/ekor. Pemeliharaan itik lokal pada tiga suhu kandang yang berbeda tidak berpengaruh nyata $(\mathrm{P}>0.05)$ terhadap bobot limpa, tiroid, dan ginjal dan kerja dari organ limpa, tiroid dan ginjal itik lokal masih] normal.
\end{abstract}

Kata Kunci: Itik lokal, konsumsi, konversi, pertambahan berat badan, suhu kandang. 


\section{PENDAHULUAN}

Potensi ternak itik di Indonesia sangat besar terutama sebagai penghasil daging dan telur. Permintaan terhadap produk peternakan meningkat setiap tahun seiring dengan bertambahnya jumlah penduduk di Indonesia serta meningkatnya pengetahuan dan kesadaran masyarakat tentang pentingnya mengkonsumsi pangan yang bergizi.

Itik di Indonesia berperan sebagai penghasil telur dan daging. Lebih dari 19\% kebutuhan telur dipenuhi dari telur itik, akan tetapi perannya sebagai penghasil daging masih rendah yaitu $0,94 \%$ dari total kebutuhan daging di Indonesia (Ketaren, 2002). Produksi daging itik di Indonesia semakin meningkat setiap tahun, hal ini dapat dilihat dari tahun 2015 produksi daging mencapai 34.854 ton, tahun 2016 mencapai 41.866 ton, tahun 2017 produksi daging mencapai 42.319 ton, pada tahun 2018 produksi daging mencapai 44.059. (BPS 2018)

Dibandingkan ternak unggas lainnya, ternak itik mempunyai potensi untuk dikembangkan karena memiliki banyak kelebihan seperti memiliki daya adaptasi yang baik, lebih rentan terhadap penyakit. Selain itu, ternak itik memiliki efiensi dalam mengubah pakan menjadi daging yang baik. (Akhadiarto, 2002)

Sumatera Barat memiliki berbagai macam itik lokal diantarannya yaitu, itik Pitalah, Sikumbang Janti, Kamang dan Bayang. Pada umumnya itik dipelihara secara ekstensif dengan melepasnya di sawah pada siang hari dan mengandangkannya pada malam hari. Untuk meningkatkan produktifitas maka itik dipelihara secara intensif dalam kandang yang diatur suhunya.

Ternak unggas tergolong hewan homeothermic (berdarah panas) dengan ciri spesifik tidak memiliki kelenjar keringat serta hampir semua bagian tubuhnya tertutup bulu, sehingga ternak akan kesusahan membuang panas tubuh apabila suhu lingkungan tinggi. Indikator adanya cekaman panas pada tubuh ternak ditandai apabila adanya peningkatan suhu rektal, suhu kulit, frekuensi pernapasan dan denyut jantung, serta menurunnya konsumsi pakan dalam upaya mengurangi pembentukan panas dan meningkatkan pengeluaran panas (Tamzil, 2014).

Suhu yang nyaman selama pemeliharaan dapat meningkatkan performa itik jadi lebih optimal. Menurut Permentan (2007), suhu optimal kandang itik ialah 26$30{ }^{\circ} \mathrm{C}$ dengan kelembaban maksimum 90\%. Data dari Badan Meteorolog, Klimatologi dan Geofisika (2009) menunjukkan rataan suhu harian Kota Payakumbuh bekisar antara $18-28{ }^{\circ} \mathrm{C}$. Dengan melihat rataan suhu harian Kota Payakumbuh, pemeliharaan itik lokal di daerah asalnya sudah tepat. Namun, tidak menutup kemungkinan itik Lokal untuk dipelihara diluar daerah asalnya yang memiliki suhu lingkungan yang lebih tinggi atau lebih rendah. Hal ini dapat dilakukan apabila mengetahui bagaimana performa itik itik yang biasa di sebut dengan itik putih di Nagari Payobasung Payakumbuh, jika dipelihara didaerah lain 
yang suhu nya berbeda dari daerah asalnya Payakumbuh.

Hal ini juga dapat dijadikan sebagai infomasi untuk mengetahui bagaimana performa itik Lokal saat dipelihara secara intensif dengan beberapa tingkatan suhu kandang yang bebeda.

\section{BAHAN DAN METODE}

Penelitian ini menggunakan itik Lokal jantan yang berasal dari daerah Payobasung, Payakumbuh Timur, kota Payakumbuh. Berat badan itik pada umur 5 minggu pada saat perlakuan suhu kandang dilakukan adalah 485-890 g/ekor. Berdasarkan rentang berat badan itik penelitian maka di hitung berat rata-rata 663,68 gram, sedangkan perhitungan kovariannya adalah 19,65\% Maka rancangan yang digunakan adalah Rancangan Acak Kelompok (RAK) karena kovarian dari berat badan itik sudah melebihi $15 \%$. Pengambilan data dimulai dari minggu kelima sampai minggu kedelapan penelitian.

Ransum yang digunakan ialah ransum komersil CP 511 Bravo pada empat minggu pertama, dan CP 512 Bravo pada minggu kelima sampai akhir penelitian. Kandungan ransum penelitian yang dipakai terdapat pada Tabel 1

Metode yang digunakan dalam penelitian ini adalah Experimen menggunakan Rancangan Acak Kelompok (RAK). Penelitian ini terdiri dari tiga (3) perlakuan berupa perbedaan suhu kandang, diantaranya:

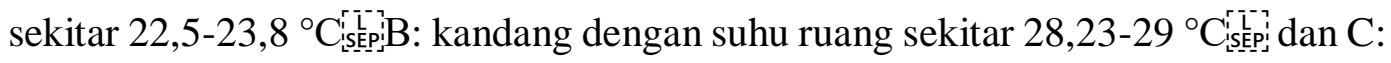
kandang dengan suhu panas sekitar 34,23-35 ${ }^{\circ} \mathrm{C}$. Dari tiga perlakuan, setiap perlakuan dibagi 6 petak sebagai kelompok dan setiap kelompok terdiri dari 3 ekor itik lokal sebagai ulangan disebut juga unit.

Model matematis yang digunakan ialah: $Y i j=\mu+\alpha i+\beta j+\in i j$

Keterangan:

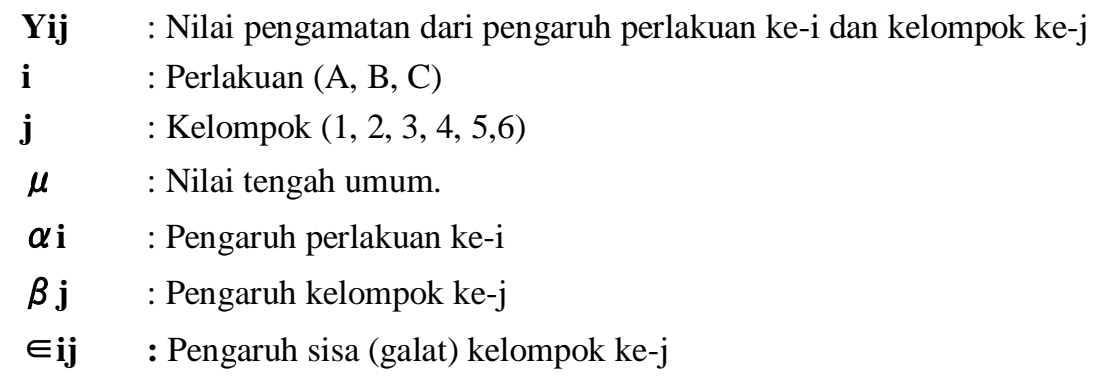

Data yang diperoleh dianalisis dengan analisis ragam. Selanjutnya untuk hasil yang signifikan dilakukan analisis uji lanjut menggunakan Uji DMRT (Duncan Multiple Range Test). 
Peubah yang diamati pada penelitian ini adalah: 1. Konsumsi ransum yang dihitung berdasarkan jumah ransum yang diberikan dikurangi dengan jumlah ransum yang tersisa. 2. Pertambahan Bobot badan dihitung dengan cara menghitung berat badan akhir dikurang berat badan awal setiap minggu penelitian 3. Konversi ransum dihitung dengan cara membandingkan dengan jumlah ransum yang dikonsumsi per ekor per minggu dibagi dengan pertambahan berat bobot badan perekor perminggu pada periode yang sama. Selanjutnya perhitungan 4. Bobot Hidup (dihitung dalam g/ekor) Bobot hidup dapat diketahui dari hasil penimbangan bobot badan seekor ternak sewaktu masih hidup setelah dipuasakan selama 12 jam (Siregar dan Sabrani, 1980). 5. Persentase Karkas (\%) Persentase karkas diperoleh dari berat karkas dibagi bobot hidup dikali 100\% ( Mountney, 1976). 6. (IOFC) 7. Pengitungan income over feed cost diperoleh dengan cara mengurangi hasil penjualan itik dengan biaya ransum yang digunakan, perhitungan dilakukan sesuai dengan semua harga pada saat penelitian.

Melihat pengaruh suhu terhadap organ dalam itik penelitian 8.Persentase bobot limpa itik, diperoleh dari pembagian antara bobot limpa dengan bobot badan akhir itik dikalikan 100\%. 9. Persentase bobot tiroid itik, diperoleh dari pembagian antara bobot tiroid dengan bobot badan akhir itik dikalikan 100\%. 10. Persentase bobot ginjal itik, diperoleh dari pembagian antara bobot ginjal dengan bobot badan akhir itik dikalikan $100 \%$.

Kandang yang digunakan dibedakan menjadi tiga buah kandang yaitu, kandang di beri AC (Air Conditioner), kandang menggunakan pemanas berupa Blower dari AC yang digunakan pada kandang suhu dingin dan kandang tanpa pengaturan suhu. Terdapat 18 unit kandang box dalam setiap perlakuan dengan ukuran (P x L x T) 70 × 70 × $60 \mathrm{~cm}$, setiap unit berisi 3 ekor itik sebagai ulangan. Peralatan yang digunakan ialah 18 buah tempat pakan, 18 buah tempat air minum, 8 buah lampu pijar 60 watt, satu unit AC (Air Conditioning) dengan merk AUX 1.1/2 PK, satu unit pemanas, satu buah gunting, plastik untuk menampung kotoran dan sekam pada bagian alas kandang. Peralatan yang digunakan untuk mendukung pengambilan data yaitu 3 buah termometer, satu buah timbangan digital dan alat tulis.

Tabel 1. Komposisi Nutrisi Ransum Komersil CP Bravo 511 dan 512 Bravo

\begin{tabular}{lcc}
\hline Zat Nutrisi & CP 511 Bravo (\%) & CP 512 Bravo (\%) \\
\hline Kadar Air & 13,0 & 13 \\
Protein kasar & 21,0 & 20,5 \\
Lemak kasar & 7,0 & 8,0 \\
Serat kasar & 6,0 & 6,0 \\
Abu & 8,0 & 8,0 \\
Kalsium & 0,90 & 0,90 \\
Phospor & 0,60 & 0,60 \\
\hline
\end{tabular}

Sumber: PT. Charoen Pokpand Indonesia (2013). 


\section{HASIL DAN PEMBAHASAN}

\section{A. Konsumsi Ransum, Pertambahan Bobot Badan dan Konversi Ransum Itik Lokal Pada Pemeliharaan Perbedaan Suhu Kandang Terhadap Konsumsi Ransum}

Rataan konsumsi ransum itik Lokal yang dipelihara pada tiga suhu kandang yang berbeda selama perlakuan dapat dilihat pada Tabel 2 .

Hasil analisis ragam menunjukkan bahwa perbedaan suhu kandang selama masa perlakuan memberikan pengaruh berbeda sangat nyata $(\mathrm{P}<0,01)$ F hitung 9,94 terhadap konsumsi ransum itik loclal. Berdasarkan tabel rataan konsumsi ransum terlihat bahwa konsumsi ransum itik Lokal berkisar antara 2964,33 - 2653,50 g/ekor. Hasil rataan tertinggi terdapat pada perlakuan A(suhu dingin) dan rataan terendah terdapat pada perlakuan B (suhu ruang). Hasil uji lanjut Duncan Multiple Range Test (DMRT) menunjukkan bahwa rataan konsumsi ransum itik Lokal pada perlakuan A berbeda sangat nyata $(\mathrm{P}<0,01)$, sedangkan perlakuan $\mathrm{B}$ dan perlakuan C secara statistik sama yaitu berbeda tidak nyata $(P>0,05)$. Perbedaan jumlah ransum yang dikonsumsi itik pada tiap perlakuan dapat dipengaruhi oleh suhu kandang yang berbeda. Suhu kandang yang terdapat pada perlakuan A berkisar antara $22,5-23,8{ }^{\circ} \mathrm{C}$. Suhu tersebut lebih tinggi dari yang diharapkan sebelumnya yaitu berkisar antara $16-18{ }^{\circ} \mathrm{C}$. Hal ini dapat disebabkan karena pengaruh suhu luar kandang yang lebih tinggi dibandingkan suhu yang ada pada kandang perlakuan dingin. Pada perlakuan B suhu kandang berkisar antara $28,23-29^{\circ} \mathrm{C}$, suhu ini sesuai dengan suhu yang diharapkan sebelumnya yaitu $26-34{ }^{\circ} \mathrm{C}$ dan pada perlakuan $\mathrm{C}$ suhu kandang berkisar antara $34,23-35{ }^{\circ} \mathrm{C}$ suhu tersebut sesuai dengan suhu yang diharapkan sebelumnya yaitu $34-40{ }^{\circ} \mathrm{C}$.

Pemeliharaan pada suhu kandang berbeda menunjukkan perbedaan jumlah ransum yang dikonsumsi. Hal ini terjadi karena suhu kandang dapat mempengaruhi tingkat kenyamanan itik dalam kandang sehingga mempengaruhi konsumsi ransum. Itik akan merasa nyaman apabila dipelihara pada suhu antara 23 sampai $25{ }^{\circ} \mathrm{C}$ (El-Badry et al., 2009). Berdasarkan penelitian yang telah dilakukan diketahui bahwa suhu kandang yang nyaman untuk itik ialah kandang suhu dingin yaitu 22,5-23,8 ${ }^{\circ} \mathrm{C}$ pada perlakuan A, sedangkan pada perlakuan B dan perlakuan $\mathrm{C}$ berada diluar suhu nyaman itik. Penelitian ini menunjukkan bahwa saat itik dipelihara pada suhu dingin maka jumlah ransum yang dikonsumsi lebih banyak dibandingkan saat dipelihara pada suhu ruang maupun panas.

Itik yang dipelihara pada zona nyaman (comfort zone) akan menunjukkan respon konsumsi ransum yang berbeda dibandingkan yang dipelihara diluar zona nyaman. Saat berada pada suhu dingin itik akan mengkonsumsi ransum lebih banyak dibandingkan saat berada pada suhu panas. Ransum yang dikonsumsi akan 
dimanfaatkan untuk menghasilkan energi. Saat suhu dingin tubuh membutuhkan banyak energi untuk menghasilkan panas, sehingga konsumsi ransum akan meningkat Rizal (2000) menyatakan bahwa, hewan cenderung mengkonsumsi pakan terus-menerus saat suhu rendah. Saat itik dipelihara pada suhu panas, itik akan mengurangi jumlah konsumsi ransum dan meningkatkan konsumsi air minum untuk mengimbangi air yang hilang saat proses evaporasi

Itik yang dipelihara pada suhu panas selama penelitian menunjukkan tingkah laku yang lebih aktif dibandingkan pada perlakuan yang lain. Hal ini merupakan salah satu penyebab konsumsi ransum yang rendah dibandingkan itik yang dipelihara pada suhu dingin. Tamzil (2014) menyatakan bahwa, suhu lingkungan yang lebih tinggi dari suhu nyaman akan menimbulkan stress panas pada itik. Stres pada itik akan mengganggu zona homeostatis dan membuat tubuh berusaha mengembalikan kondisi sebelum terjadi stres. Kondisi stres tersebut akan mengaktifkan mekanisme termoregulasi dalam upaya mengurangi pembentukan panas dan meningkatkan pengeluaran panas dengan cara meningkatkan suhu rektal, suhu kulit, denyut jantung, frekuensi pernapasan, serta menurunkan konsumsi ransum. Itik yang dipelihara pada suhu ruang juga memiliki konsumsi ransum yang rendah dibandingkan itik yang dipelihara pada suhu dingin. Rataan konsumsi ransum itik yang dipelihara pada suhu ruang ialah sebesar 2653,50 gram/ekor, konsumsi ini lebih rendah dibandingkan penelitian Supriatman (2017) yang memberikan ransum komersil untuk pakan itik lokal dengan rataan konsumsi pakan sebesar 2950,96 gram/ekor. Dalam penelitian pakan yang digunakan merupakan pakan komersil, sehingga kandungan energi, palatabilitas, kecernaan serta komposisi zatpakan dalam ransum semuanya sama. Namun untuk suhu kandang selama pemeliharaan pada masing-masing perlakuan berbeda, sehingga dapat menyebabkan perbedaan jumlah konsumsi ransum pada setiap perlakuan tersebut

\section{Terhadap Pertambahan Bobot Badan Itik Lokal}

Rataan pertambahan bobot badan Itik Lokal pada masing-masing penelitian dapat dilihat pada Tabel 2

Hasil analisis ragam menunjukkan bahwa perbedaan suhu kandang selama pemeliharaan memberikan pengaruh berbeda sangat nyata $(\mathrm{P}<0,01) \mathrm{F}$ hitung 24,58 terhadap pertambahan bobot badan itik. Berdasarkan tabel pertambahan bobot badan menunjukkan bahwa pertambahan bobot badan itik Lokal selama perlakuan berkisar antara 711,83-483,89 g/ekor. Pertambahan bobot badan tertinggi terdapat pada perlakuan A dan rataan terendah terdapat pada $\mathrm{C}$.

Hasil uji lanjut DMRT menunjukkan bahwa rataan pertambahan bobot badan itik Lokal pada perlakuan A dan B berbeda nyata $(P<0,05)$, namun berbeda sangat nyata $(\mathrm{P}<0,01)$ terhadap perlakuan $\mathrm{C}$. Pertambahan bobot badan tertinggi terdapat 
pada perlakuan A dengan rata-rata 711,83 g/ekor, pada perlakuan B dengan ratarata 626,11 g/ekor, sedangkan pertambahan bobot badan terendah dengan rata-rata 483,89 g/ekor terdapat pada perlakuan C.

Berdasarkan tabel rataan pertambahan bobot badan diketahui bahwa itik yang dipelihara pada perlakuan A pada kandang suhu dingin memiliki rata-rata pertambahan bobot badan paling tinggi dibandingkan perlakuan tanpa suhu dingin. Kandang dengan perlakuan suhu dingin memiliki rata-rata suhu sekitar 22,5-23,8 ${ }^{\circ} \mathrm{C}$. Suhu kandang tersebut merupakan suhu yang paling cocok untuk pemeliharaan itik Lokal. Suhu tersebut sesuai dengan suhu yang ada pada daerah asal itik Lokal yaitu kota Payakumbuh. Kota Payakumbuh memiliki rentang suhu antara $18-28{ }^{\circ} \mathrm{C}$ (Badan Meteorologi, Klimatologi dan Geofisika, 2019). Hal ini menunjukkan bahwa pemeliharaan itik Lokal pada daerah asalnya dinilai telah tepat, namun tidak menutup kemungkinan bahwa itik tersebut dapat dipelihara diluar daerah asalnya. Hal ini dapat dilakukan dengan memperhatikan kandungan nutrisi ransum serta sistem pemeliharaan itik Lokal tersebut. Sistem pemeliharaan yang digunakan ialah pemeliharaan secara intensif dengan mengatur suhu dalam kandang menjadi kondisi yang nyaman bagi itik.Suhu dalam kandang dapat diatur dengan menggunakan pendingin ruangan. Pengaturan suhu dalam kadang juga dapat dilakukan seperti yang ada pada sistem closed house.

Pemeliharaan itik secara intensif pada tiga suhu kandang yang berbeda menunjukkan pertambahan bobot badan yang lebih tinggi dibandingkan itik Lokal yang dipelihara secara semi-intensif. Berdasarkan penelitian yang dilakukan oleh Ricardo (2016) ang menggunakan itik Lokal dengan sistem pemeliharaan semiintensif selama delapan minggu, rata-rata bobot badan yang dihasilkan ialah 026 g/ekor. Hasil ini lebih rendah dibandingkan rataan bobot badan itik Lokal yang dipelihara selama delapan minggu secara intensif dengan suhu kandang yang berbeda, yaitu 1371,3 g/ekor pada perlakuan A, 1292,4 g/ekor pada perlakuan B dan 1149,1 g/ekor pada perlakuan C. Berdasarkan perbandingan sistem pemeliharaan itik Lokal, dapat dilihat bahwa itik yang dipelihara dengan sistem intensif menunjukkan performa terbaik dibandingkan itik yang dipelihara secara semi- intensif. Dan itik yang dipelihara pada suhu dingin dengan sistem intensif, menunjukkan performa terbaik dibandingkan itik yang dipelihara pada suhu ruang dan suhu panas.

Buwono (2007) menambahkan bahwa, bobot badan dipengaruhi oleh kualitas dan kuantitas pakan yang dikonsumsi. Perbedaan kandungan zat-zat makanan pada pakan dan banyaknya pakan yang dikonsumsi akan memberikan pengaruh terhadap pertambahan bobot badan yang dihasilkan. Kandungan zat-zat pakan yang seimbang dan sesuai dengan kebutuhan sangat diperlukan untuk pertumbuhan yang optimal. Kebutuhan ternak itik terhadap kandungan nutrisi pakan tergantung 
kepada tingkat pertumbuhan itik.

Memasuki periode pertumbuhan diperlukan pakan dengan zat makanan yang seimbang. Kandungan zat makanan yang menentukan performa pada unggas adalah imbangan protein dan energinya. Selain itu, kebutuhan vitamin dan mineral juga harus terpenuhi (Simamora, 2011). Tubuh hewan akan mengalami pertumbuhan yang cepat sejak hewan lahir sampai dewasa kelamin. Setelah dewasa kelamin pertumbuhan hewan masih berlanjut walaupun pertumbuhan berjalan dengan lambat tapi pertumbuhan tulang dan otot pada saat itu telah berhenti (Kurnia, 2011). Pada itik pertumbuhan tercepat serta pertambahan bobot badan tertinggi terjadi pada periode starter dan selanjutnya menurun pada saat dewasa (Rositawati, dkk, 2010). Purba dan Ketaren (2011) menyatakan bahwa, selama fase pertumbuhan, itik umumnya membutuhkan pakan yang relatif banyak dan berkualitas agar dapat tumbuh dan berkembang dengan sempurna. Penelitian ini menunjukan sebaliknya, bahwa selain pakan yang berkualitas suhu lingkungan kandang juga mempengaruhi pertambahan bobot badan

\section{Terhadap Konversi Ransum Itik Lokal}

Rataan konversi ransum itik Lokal pada masing-masing perlakuan selama penelitian dapat dilihat pada Tabel 2.

Hasil analisis ragam menunjukkan bahwa perbedaan suhu kandang selama masa perlakuan menunjukkan pengaruh berbeda sangat nyata $(\mathrm{P}<0,01) \mathrm{F}$ hitung 16,42 terrhadap konversi ransum itik. Berdasarkan tabel konversi ransum diketahui bahwa konversi ransum tertinggi terdapat pada perlakuan $\mathrm{C}$ dan konversi ransum terendah terdapat pada perlakuan A. Hasil uji lanjut DMRT menunjukkan bahwa rataan konversi ransum itik Lokal pada perlakuan $\mathrm{C}$ berbeda sangat nyata, sedangkan pada perlakuan A dan perlakuan B sama secara statistik yaitu bebeda tidak nyata $(\mathrm{P}>0,05)$ F hitung 4,21.

Semakin kecil angka konversi ransum menunjukkan bahwa peforma itik tersebut semakin baik. Berdasarkan hasil yang diperoleh, diketahui bahwa rataan konversi ransum terendah terdapat pada perlakuan A yaitu sebesar 4,22. Angka konversi ransum yang kecil menunjukkan semakin sedikitnya ransum yang digunakan untuk menghasilkan satu kilogram daging (Kartasudjana dan Supriyatna, 2006). Hal ini menunjukkan bahwa saat itik dipelihara pada suhu dingin, performa itik tersebut semakin membaik.

Itik yang berada pada suhu ruang pada perlakuan B menghasilkan rataan konversi ransum sebesar 4,29. Hasil tersebut lebih tinggi dibandingkan dengan perlakuan A pada suhu dingin, namun nyata lebih rendah dibandingkan dengan perlakuan $\mathrm{C}$ pada suhu panas. 
Tabel 2. Rataan konsumsi ransum, Pertambahan Bobot Badan dan Konversi Ransum Itik Lokal jantan selama perlakuan

\begin{tabular}{lccc}
\hline Perlakuan & $\begin{array}{c}\text { Konsumsi ransum } \\
(\text { g/ekor) }\end{array}$ & $\begin{array}{c}\text { Pertambahan bobot } \\
\text { badan (g/ekor) }\end{array}$ & Konversi ransum \\
\hline A (suhu dingin) & $2964,33^{\mathrm{A}}$ & $711,83^{\mathrm{Aa}}$ & $4,22^{\mathrm{B}}$ \\
B (suhu ruang) & $2653,50^{\mathrm{B}}$ & $626,11^{\mathrm{Ab}}$ & $4,29^{\mathrm{B}}$ \\
C (suhu panas) & $2668,00^{\mathrm{B}}$ & $483,89^{\mathrm{B}}$ & $5,61^{\mathrm{A}}$ \\
\hline SE & 55,63 & 23,22 & 0,19 \\
\hline
\end{tabular}

Keterangan: A,B Superskrip yang berbeda pada kolom yang sama menunjukkan pengaruh sangat nyata $(\mathrm{P}<0,01)$, a $\mathrm{b}$ : Superskrip yang berbeda pada kolom menunjukkan pengaruh nyata $(\mathrm{P}<0,05)$

Rataan konversi ransum pada perlakuan $\mathrm{C}$ adalah yang paling tinggi dibandingkan dua perlakuan lainnya. Rataan konversi ransum pada perlakuan $\mathrm{C}$ ialah sebesar 5,61. Semakin tinggi angka konversi ransum menunjukkan semakin borosnya penggunaan ransum. Itik yang dipelihara pada zona thermoneutralnya memanfaatkan energi dari ransum untuk pertumbuhan, pengembangan sistem kekebalan tubuh dan untuk reproduksi. Ketika itik berada pada lingkungan dibawah suhu thermoneutralnya, energi dari pakan akan digunakan untuk menghasilkan panas daripada untuk pertumbuhan, pengembangan sistem kekebalan tubuh dan reproduski. Jika suhu lingkungan lebih tinggi dari suhu thermoneutral itik, suhu tubuh akan naik dan itik akan menggunakan sebagian energi untuk melepaskan panas, sehingga cenderung mengurangi efisiensi dari konversi ransum. Itik yang mengalami stres panas akan mengurangi konsumsi ransum, mengalami penurunan bobot badan dan menghasilkan konversi ransum yang buruk. Stres panas juga dapat meningkatkan laju pernapasan (terengah-engah) pada itik

Kandungan nutrisi pakan yang diperlukan untuk pertumbuhan sangat dipengaruhi oleh umur, bangsa, jenis kelamin, laju pertumbuhan dan penyakit. Kesehatan unggas juga mempengaruhi nilai konversi ransum. Berdasarkan penelitian yang telah dilakukan diketahui bahwa umur, bangsa dan jenis kelamin itik yang dipelihara ialah sama dan juga itik tersebut tidak terserang penyakit. Tingginya konversi pakan dapat disebabkan karena terjadinya penurunan berat badan itik saat berumur 8 minggu, sedangkan pakan yang dikonsumsi tetap tinggi.

Berdasarkan penelitian yang telah dilakukan diketahui bahwa terdapat perbedaan suhu kandang selama perlakuan. Pada perlakuan A rataan suhu kandangnya bekisar antara $22,5-23,8^{\circ} \mathrm{C}$, pada perlakuan B bekisar antara 28,23$29{ }^{\circ} \mathrm{C}$ dan pada perlakuan $\mathrm{C}$ berkisar antara 34,23-35 VC. Hal ini menunjukkan bahwa pemeliharaan itik pada suhu dingin dapat membuat performa itik khususnya konversi ransum lebih baik dibandingkan saat itik dipelihara pada suhu ruang maupun suhu panas. Tingginya konversi ransum itik dapat disebabkan oleh kebiasaan itik yang segera mencari air minum setelah makan. Pada umumnya pakan 
tercecer atau terbuang pada saat itik pindah dari tempat pakan ke tempat minum dan juga terlarut dalam air minum saat itik tersebut minum. Hardjosworo (2005) menambahkan, penempatan tempat air minum yang terpisah dari tempat pakan menyebabkan pakan tercecer antara tempat minum dan tempat pakan atau kedalam tempat air minum itu sendiri.

\section{B. Pengaruh Perlakuan Terhadap Bobot Hidup, Persentase Karkas dan IOFC (Income Over Feed Cost) Itik Lokal Jantan Selama Penelitia}

\section{Terhadap Bobot Hidup}

Dari hasil penelitian yang telah dilakukan, diperoleh rataan bobot hidup, persentase karkas dan (Income overfeed cost) itik Lokal jantan yang dipelihara pada tiga suhu kandang yang berbeda selama penelitian (Tabel 3).

Pada Tabel 3. Terlihat bahwa rataan bobot hidup itik Lokal jantan dengan perlakuan suhu kandang yang berbeda berkisar antara 1179 g/ekor sampai 1437 g/ekor. Rataan bobot hidup tertinggi terdapat pada perlakuan A (suhu rendah) yaitu 1437 g/ekor, sedangkan rataan bobot hidup terendah terdapat pada perlakuan C (suhu panas) yaitu $1179 \mathrm{~g}$ /ekor. Hasil analisa sidik ragam menunjukkan perlakuan suhu kandang yang berbeda selama masa pemeliharaan itik lokal jantan menunjukkan pengaruh berbeda sangat nyata $(\mathrm{P}<0,01) \mathrm{F}$ hitung 16,21 terhadap pertambahan bobot hidup itik lokal jantan.

Hasil uji lanjut Duncan Multiple Range Test menunjukkan bahwa rataan bobot hidup itik Lokal jantan pada perlakuan A (suhu rendah) memiliki bobot hidup paling tinggi, berbeda tidak nyata terhadap perlakuan B (suhu kandang) dan berpengaruh lebih tinggi terhadap perlakuan $\mathrm{P}_{3}$ (suhu panas). Kandang perlakuan A (suhu rendah) memiliki rataan suhu 22,5 sampai $23,8{ }^{\circ} \mathrm{C}$. Suhu kandang tersebu merupakan suhu paling cocok untuk pemeliharaan itik jantan, karena suhu pada daerah asal itik yaitu Kota Payakumbuh sesuai dengan suhu rendah pada perlakuan.

Pemeliharaan itik pada daerah asalnya di Payobasung Payakumbuh sudah tepat karena sesuai dengan keadaan lingkungan aslinya, tetapi tidak menutup kemungkinan itik Lokal ini dipelihara diluar daerah asalnya dengan memperhatikan sistem pemeliharaannya, dengan cara pemeliharaan secara intensif dan mengatur iklim mikro dalam kandang menjadi kondisi yang nyaman bagi itik dengan menggunakan AC (Air Conditioner). Pada penelitian ini perlakuan A dengan rataan suhu 22,5-23,8 ${ }^{\circ} \mathrm{C}$ memperoleh bobot hidup mencapai 1437 g/ekor merupakan rataan bobot hidup paling tinggi. Hal ini sesuai dengan pendapat El-Badry et al., (2009) yang menyatakan bahwa thermo-neutral zone untuk ternak unggas yaitu antara $18-25^{\circ} \mathrm{C}$ dan untuk ternak itik lokal yaitu antara $23-25^{\circ} \mathrm{C}$. 
Tabel 3. Hasil rataan bobot hidup, persentase karkas, dan IOFC itik lokal antan selama penelitian.

\begin{tabular}{cccc}
\hline Perlakuan & $\begin{array}{c}\text { Bobot Hidup } \\
\text { (gram/ekor) }\end{array}$ & $\begin{array}{c}\text { Persentase Karkas } \\
(\%)\end{array}$ & IOFC (Rp/ekor) \\
\hline A.(suhu rendah) & $1437^{\mathrm{A}}$ & 66,56 & $3.775,15$ \\
B (suhu kandang) & $1354^{\mathrm{A}}$ & 64,18 & $2.925,51$ \\
C (suhu panas) & $1179^{\mathrm{B}}$ & 67,64 & $-2.881,63$ \\
\hline SE & 41,53 & 1.95 &
\end{tabular}

Keterangan: Superskrip yang berbeda pada kolom yang sama menunjukkapengaruh berbeda sangat nyata $(\mathrm{P}<0,01)$

Pada perlakuan B dengan rataan suhu $28,2-29{ }^{\circ} \mathrm{C}$ memperoleh bobot hidup selama penelitian mencapai 1354 g/ekor, dan perlakuan C dengan rataan suhu 34,235,04 ${ }^{\circ} \mathrm{C}$ memperoleh bobot hidup selama penelitian mencapai 1179 g/ekor. Saat suhu dingin tubuh membutuhkan banyak energi untuk menghasilkan panas, sehingga konsumsi ransum meningkat El-Badry et al., (2009) menyatakan bahwa, hewan cenderung mengkonsumsi pakan terus-menerus saat suhu rendah. Saat itik diperlihara pada suhu panas itik cenderung akan mengurangi jumlah konsumsi ransum dan meningkatkan konsumsi air minum untuk mengimbangi air yang hilang pada saat proses evaporasi

Itik yang dipelihara pada suhu panas selama penelitian menunjukkan tingkah laku yang lebih aktif dibandingkan perlakuan suhu dingin dan suhu kandang. Menurut Tamzil (2014) menyatakan bahwa, suhu lingkungan yang lebih tinggi dari suhu nyaman akan menimbulkan stress panas pada itik. Stres pada itik akan menganggu zona homeostatis dan membuat tubuh berusaha mengembalikan kondisi sebelum terjadi stres. Kondisi stres tersebut akan mengaktifkan mekanisme termoregulasi dalam upaya mengurangi pembentukan panas dan meningkatkan pengeluaran panas dengan cara meningkatkan suhu rektal, suhu kulit, denyut jantung, frekuensi pernapasan, serta menurunkan konsumsi pakan sehingga berpengaruh terhadap bobot hidup itik yang diperoleh.

Hasil penelitian ini didapatkan rataan bobot hidup itik yang paling tinggi pada perlakuan A yaitu 1437 g/ekor. Sedangkan Penelitian Suswoyo dan Ismoyowati (2010) mengatakan bobot badan itik dewasa pada sistem intensif sebesar 1290 g/ekor, sedangkan pada sistem gembala 1153 g/ekor. Hasilnya tidak berbeda jauh dengan penelitian pada perlakuan B dan perlakuan C.

Hasil penelitian Hadi (2016) mengatakan bahwa pemeliharaan itik Kamang jantan periode starter dengan kepadatan kandang 3 ekor/0,3 $\mathrm{m}^{2}$ yang dipelihara selama 8 minggu dengan pemberian protein $18 \%$ mendapatkan bobot hidup 1259 g/ekor. Hasilnya tidak berbeda jauh pada perlakuan B dan perlakuan C yaitu 1354 g/ekor dan 1179 g/ekor yang menggunakan pakan komersil CP 512 Bravo dengan protein $20,5 \%$. Dari hasil penelitian yang telah dilakukan, diperoleh rataan 
persentase karkas itik Lokal Jantan yang dipelihara pada tiga suhu kandang yang berbeda selama penelitian dapat dilihat pada Tabel 2

\section{Terhadap Persentase Karkas}

Pada Tabel 3. Terlihat bahwa rataan persentase karkas dengan perlakuan suhu kandang yang berbeda berkisar antara $64,49 \%$ sampai $65,56 \%$. Rataan persentase karkas tertinggi terdapat pada perlakuan $\mathrm{C}$ (suhu panas) yaitu 67,64\%, sedangkan rataan persentase karkas terendah terdapat pada perlakuan B (suhu kandang) yaitu 64,18\%. Hasil analisis keragaman menunjukkan bahwa perlakuan dengan perbedaan suhu kandang selama masa pemeliharaan itik memberikan pengaruh tidak nyata $(\mathrm{P}>0,05)$ terhadap persentase karkas itik Lokal. Hal ini menunjukkan bahwa pada penelitian ini perbedaan suhu kandang tidak memberikan hasil persentase karkas yang berbeda.

Menurut penelitian Ricardo (2016) yang menyimpulkan bahwa pemeliharaan itik Lokal di Pembibitan Itik "ER" Payobasung, Payakumbuh selama 8 minggu, mendapatkan hasil persentase karkas itik Lokal 44,95\%. Hasil penelitian ini lebih rendah dikarenakan sistem pemeliharaan pada penelitian ini dilakukan secara semi intensif sehingga persentase karkas yang dihasilkan lebih rendah dari pada sistem pemeliharaan pada tingkatan suhu yang berbeda.

Menurut penelitian Hadi (2016) bahwa rataan persentase karkas yang diperoleh dari pemeliharaan itik Kamang jantan periode starter dengan kepadatan kandang 3 ekor/0,3 $\mathrm{m}^{2}$ yang dipelihara selama 8 minggu adalah $64,61 \%$. Hasil penelitian ini tidak jauh berbeda dengan perlakuan A yaitu 65,56 \% karena samasama itik Sumatera Barat

Menurut penelitian Musyaffa (2019) menyatakan bahwa rataan persentase karkas yang didapatkan dari pemeliharaan itik Lokal dengan perlakuan pengaruh suplementasi tepung temulawak (Curcuma xanthoriza Roxb) dan mineral zink dalam ransum yang mengalami cekaman panas memperoleh persentase karkas antara 57,67\%. Hasil penelitian ini cukup berbeda dengan perlakua $\mathrm{C}$ dikarenakan oleh faktor ransum yang diberikan terhadap itik Lokal, sehingga mendapatkan bobot hidup yang tinggi dan memperoleh persentase karkas yang cukup tinggi. Pada penelitian Musyaffa menggunakan suplementasi tepung temulawak serta ransum yang diberikan merupakan ransum yang diaduk sendiri sesuai dengan kebutuhan itik, sedangkan pada penelitian ini menggunakan pakan komersil CP 512 Bravo serta suhu yang cocok untuk memacu pertumbuhan itik Lokal.

Dewanti et al (2013) menyatakan bahwa persentase bagian-bagian karkas berhubungan erat dengan bobot karkas, sedangkan bobot karkas dipengaruhi oleh bobot hidup. Lebih lanjut Dewanti et al., (2013) melaporkan bahwa persentase karkas dipengaruhi oleh bobot potong. 


\section{Terhadap Income Over Feed Cost (IOFC)}

Nilai IOFC ditentukan oleh selisih penjualan itik dan biaya pakan yang dikeluarkan. sesuai dengan pendapat Rasyaf (2004) yang menyatakan bahwa semakin efisien unggas mengubah makanan menjadi daging (konversi pakan yang baik) maka semakin baik nilai IOFC yang didapatkan

Pada Tabel 3 dapat dilihat total IOFC itik jantan selama penelitian menunjukkan perbedaan disetiap perlakuan berkisar antara Rp. -2.881,63/ekor sampai dengan Rp. 3.775,15/ekor. Perhitungan IOFC tertinggi terdapat pada perlakuan A (suhu rendah), hal ini menunjukkan hasil pendapatan yang lebih baik dibandingkan dengan perlakuan lainnya. Hal ini pada perlakuan A (suhu rendah) memperoleh pertumbuhan bobot badan lebih tinggi dibandingkan perlakuan B (suhu kandang), dan perlakuan C (suhu panas), sedangkan konsumsi pakan perlakuan A (suhu rendah) tidak berbeda jauh dengan perlakuan B (suhu kandang) dan perlakuan $\mathrm{C}$ (suhu panas).

Tinggi rendahnya IOFC dari setiap perlakuan disebabkan oleh bobot akhir serta konsumsi itik Lokal yang berbeda pada setiap perlakuan. Jika konsumsi pakan sedikit dan bobot badan yang tinggi maka memberikan keuntungan yang maksimal kecepatan pertumbuhan ternak salah satunya ditentukan oleh jumlah ransum yang dikonsumsi, jika ransum yang dikonsumsi relatif sedikit maka pertumbuhan akan lambat.

Menurut Rasyaf (2004) menyatakan bahwa biaya pakan yang tinggi sangat mempengaruhi selisih antara pendapatan dengan biaya ransum. Menurut Rasyaf (2004) menyatakan bahwa semakin tinggi nilai IOFC akan semakin baik pula pemeliharaan yang dilakukan, karena tingginya income over feed cost bearti penerimaan yang didapat dari hasil penjualan itik juga semakin tinggi.

Menurut penelitian Lubis (2017) menyatakan bahwa keuntungan pemeliharaan itik Pitalah selama penelitian dengan perlakuan pengaruh pemberian kulit kayu fermentasi (kukaf) dengan Bacillus amyloliquefaciens dalam ransum berkisar antara Rp. 7741,-/ekor sampai dengan Rp. 8432,-/ekor. Menurut penelitian Riani (2017) menyatakan bahwa keuntungan yang didapatkan selama penelitian itik Lokal dengan perlakuan pengaruh frekuensi pemberian ransum secara periodik dan level protein berkisar antara Rp. 10345,-/ekor sampai dengan 21968,-/ekor. Menurut Rasyaf (2004) faktor-faktor yang mempengaruhi adalah IOFC harga ransum, jumlah konsumsi, dan harga penjualan. Salah satu upaya untuk memperoleh nilai IOFC yang baik adalah dengan menekan biaya ransum dengan peningkatan pengawasan terhadap pemberian pakan dan pemilihan pakan yang baik mutunya, sesuai dengan kebutuhan itik dan harga yang tidak terlalu mahal 


\section{Pengaruh Perlakuan Terhadap Persentase Bobot Limpa, Tiroid dan Ginjal}

\section{Terhadap Bobot Limpa}

Berdasarkan penelitian yang telah dilaksanakan, rataan bobot limpa itik Lokal yang dipelihara pada tiga suhu kandang yang berbeda selama penelitian dapat dilihat pada Tabel 4

Berdasarkan hasil analisis sidik ragam menunjukkan bahwa pemeliharaan pada suhu kandang berbeda memberikan pengaruh Tidak berbeda nyata $(\mathrm{P}>0,05) \mathrm{F}$ hitung terrhadap bobot limpa itik lokal. Tidak berpengaruh nyatanya kemungkinan disebabkan kurangnya cekaman dingin dan cekaman panas serta waktu cekaman yang tergolong relatif tidak stabil pada kandang 1.suhu dingin dan suhu panas. Selain itu, pengaruh suhu lingkungan di luar kandang yang relatif tidak stabil juga memberikan dampak pada keadaan suhu di dalam kandang.

Kurang stabilnya suhu didalam kandang disebabkan kurangnya peralatan yang digunakan, terutama pendingin dan pemanas ruangan. Pada penelitian ini pendingin ruangan yang digunakan hanya satu $A C$ dan pemanas yang memanfaatkan panas dari mesin $A C$ dan lampu pijar. Dengan luas ruangan berukuran $3 \times 3 \mathrm{~m}$ serta hanya menggunakan satu pendingin ruangan, tidak dapat membuat suhu ruangan dingin tercekam. Begitu juga dengan kandang suhu panas, panas yang dihasilkan dari mesin $A C$ hanya sedikit meningkatkan suhu dari suhu disekitar kandang dan penambahan lampu pijar hanya dapat meningkat suhu didalam kandang box, tidak meningkatkan keseluruhan ruangan kandang.

Pada Tabel 4 rataan bobot limpa terlihat bahwa bobot limpa itik Lokal yang di pelihara pada tiga suhu kandang yang berbeda berkisar antara 89,40 mg$95,52 \mathrm{mg} / 100 \mathrm{~g}$ bobot badan atau setara dengan 0,09-0,10\%, bobot badan. Rataan persentase limpa itik lokal yang dipelihara pada tiga suhu kandang berbeda menunjukan masih dalam kisaran normal. Hal ini sejalan dengan hasil penelitian yang dilaporkan oleh Heckert et al. (2002) pada ayam, yang menunjukan bahwa bobot limpa ayam berkisar antara $88-156 \mathrm{mg} / 100 \mathrm{~g}$ bobot badan atau setara dengan $0,09-0,16 \%$ bobot badan.

Tabel 4. Rataan persentase bobot limpa, tiroid dan ginjal (100mg/bobot badan) itik lokal pada akhir penelitian

\begin{tabular}{cccc}
\hline Perlakuan & Persts Limpa & Persentase Tiroid & Rataan Psts Ginjal \\
\hline A (suhu dingin) & 95,52 & 6,96 & 1106,53 \\
B (suhu ruang) & 92,57 & 6,65 & 1211,21 \\
C (suhu panas) & 89,40 & 6,63 & 1237,96 \\
\hline SE & 4,49 & 0,40 & 83,95 \\
\hline
\end{tabular}

Keterangan :ns : Berbeda Tidak nyata $(\mathrm{P}>0,05)$ 
Menurut Kusnaidi dan Julardi (2010) bahwa pemberian stress pada ayam tidak memberikan pengaruh nyata terhadap bobot limpa. Bobot limpa juga di pengaruhi oleh jumlah darah yang dari jantung, hal ini sesuai dengan pernyataan Rahmawati (201)), bahwa limpa merupakan salah satu organ yang berkaitan dengan sistem sirkulasi yang berfungsi sebagai penampung darah, sehingga ukurannya tergantung jumlah darah pada saat itu. Demikian pula dengan semakin meningkatnya bobot tubuh, bobot limpa akan meningkat karena volume darah meningkat dengan semakin besarnya bobot tubuh (Rahmawati, 2010).

\section{Terhadap Bobot Tiroid}

Berdasarkan penelitian yang telah dilaksanakan, rataan bobot tiroid itik Lokal yang dipelihara pada tiga suhu kandang yang berbeda selama penelitian dapat dilihat pada Tabel 4.

Berdasarkan Tabel 4 dapat di lihat bahwa rataan bobot tiroid itik Lokal yang dipelihara pada tiga suhu kandang yang berbeda berkisar antara 6,31 mg- $\quad 6,96$ $\mathrm{mg} / 100 \mathrm{~g}$ bobot badan atau setara dengan $0,006-0,007 \%$ bobot badan. Rataan bobot tiroid itik lokal yang dipelihara pada tiga suhu kandang berbeda yang dihasilkan masih dalam kisaran normal. Hal ini sejalan dengan pendapat yang dikemukan Sturkie (2000) bahwa bobot tiroid unggas berkisar antara 0,004- 0,007 \% dari bobot badan.

Suhu kadang diatas dan dibawah suhu normal yang dikhawatirkan dapat mengakibatkan stress yang pada kelanjutannya dapat menyebabkan fungsi tiroid terganggu ternyata berpengaruh tidak nyata terhadap bobot tiroid, ini menandakan bahwa kelenjar tiroid tidak terganggu. Selain pengaruh suhu kandang, ada faktor lain yang juga mempengaruhi bobot tiroid itik.

Hasil yang diperoleh pada saat penelitian dengan perlakuan tiga suhu kandang yang berbeda pada itik lokal memberikan pengaruh tidak berbeda nyata $(\mathrm{P}>0,05) \mathrm{F}$ hitung 0,79 terrhadap bobot tiroid. Tidak berpengaruhnya pemberian perlakuan suhu pada itik lokal ini diduga karena kurangnya cekaman dingin dan cekaman panas serta waktu cekaman yang tergolong relatif tidak stabil pada kandang suhu dingin dan suhu panas. Selain itu, pengaruh suhu lingkungandi luar kandang yang relatif tidak stabil juga memberikan dampak pada keadaan suhu di dalam kandang.

Suhu kandang yang masih toleran untuk itik lokal membuat bobot kelenjar tiroid berbeda tidak nyata dengan perlakuan suhu yang diberikan. Untuk memberikan pengaruh nyata terhadap bobot kelenjar tiroid mungkin dapat dilakukan dengan menurunkan dan menaikan suhu lebih rendah, sehingga aktifitas kelenjar tiroid terganggu. Sesuai laporan Hoffman dan Shaffner (1950) bahwa kelenjar tiroid yang lebih berat diketahui meningkat fungsinya, sehingga terdapat hubungan positif antara aktifitas kelenjar tiroid dengan beratnya. Serta Soeharsono 
(1976) menyatakan bahwa sekresi kelenjar tiroid (tiroksin) merupakan indikator adanya efek suhu, sekresi hormon ini akan lebih tinggi pada ayam yang dipelihara pada suhu rendah, sedangkan pada suhu tinggi sekresi hormon ini menurun.

\section{Persentase Bobot Ginjal}

Berdasarkan penelitian yang telah dilaksanakan, rataan bobot ginjal itik Lokal yang dipelihara pada tiga suhu kandang yang berbeda selama penelitian dapat dilihat pada Tabel 4 diatas.

Hasil analisis keragaman yang diperoleh pada saat penelitian dengan perlakuan pemeliharaan tiga suhu kandang yang berbeda memberikan pengaruh Tidak berbeda nyata $(\mathrm{P}>0,05) \mathrm{F}$ hitung 0.84 rhadap bobot ginjal itik lokal. Tidak berpengaruh nyatanya perlakuan kemungkinan disebabkan kurangnya cekaman dingin dan cekaman panas serta waktu cekaman yang tergolong relatif tidak stabil pada kandang suhu dingin dan suhu panas.Selain itu, pengaruh suhu lingkungan di luar kandang yang relatif tidak stabil juga memberikan dampak pada keadaan suhu di dalam kandang.

Bobot ginjal yang tidak terpengaruh oleh perlakuan dapat disebabkan juga oleh seimbangnya cairan dalam tubuh itik lokal, yang mana fungsi utama ginjal adalah memproduksi urine melalui proses filtrasi dan reabsorbsi beberapa nutrient dengan demikian ginjal memiliki peran dalam pengaturan keseimbangan cairan tubuh. Pada Tabel 4 dapat dilihat bahwa rataan bobot ginjal itik lokal yang dipelihara pada tiga suhu kandang berbeda selama penelitian berkisar antara 1106,53-1237,96 (mg/100 g) bobot badan atau setara dengan 1,1-2\% bobot badan. Hal ini sesuai dengan yang laporan Sturkie (2000) pada bobot ginjal ayam, bahwa bobot normal ginjal ayam berkisar antara 1-2,6 \% dari bobot badan.

\section{SIMPULAN}

Berdasarkan hasil penelitian yang telah dilakukan dapat disimpulkan bahwa pemeliharaan itik Lokal pada tiga suhu kandang yang berbeda, berpengaruh sangat nyata $(\mathrm{P}<0,01)$ terhadap konsumsi ransum dan pertambahan bobot badan, namun tidak berpengaruh terhadap konversi ransum. Hasil terbaik terdapat pada suhu kandang dingin dengan konsumsi ransum sebesar 2964,33 g/ekor, pertambahan bobot badan sebesar 711,83 g/ekor selama penelitian, bobot hidup sebesar 1437 gram/ekor, dan konversi ransum 4,22 Sedangkan persentase karkas tidak berpengaruh nyata $\mathrm{P}>0.05$ ) yaitu $67,64 \%$ yang menghasilkan Hasil IOFC (income over feed cost) hasil yang paling tinggi kandang pada suhu dingin dengan keuntungan sebesar Rp. 3.375,15/ekor. Pemeliharaan itik lokal pada tiga suhu kandang yang berbeda tidak berpengaruh nyata $(\mathrm{P}>0.05)$ terhadap bobot limpa, 
tiroid, dan ginjal dan kerja dari organ limpa, tiroid dan ginjal itik lokal masih normal.

\section{UCAPAN TERIMA KASIH}

Ucapan terima kasih kepada LPPM Unand melalui Fakutas Petenakan telah mendanai penelitian ini melalui hibah Dana Fakultas Peternakan tahun 2019. Terima kasih kepada Miftahul Hidayana dan Ilham Yuhendar atas bantuan pengambilan data dikandang dan di laboratorium Fakultas Paternakan Universitas Andaas Padang.

\section{DAFTAR PUSTAKA}

Badan Meteorologi, Klimatologi dan Geofisika. 2019. Prakiraan Cuaca Payakumbuh (Kota Payakumbuh)-Sumatera Barat. BMKG.

BPS Sumbar. 2010. Produksi daging ternak, konsumsi daging dan telur tahun 2001-2010. Padang (Indonesia): Badan Pusat Statistik Provisi Sumatera Barat

Buwono, F. A. 2007. Pengaruh tingkat protein pakan dan frekuensi pemberian pakan terhadap kinerja itik Mojosari (Anas domesticus) jantan periode awal. Skripsi. Universitas Brawijaya, Malang.

Direktorat Jendral, Peternakan. 2017. Statistik Peternakan dan Kesehatan Hewan.Livestock And Animal Health Statistic 2017. Jakarta.

El-Badry, A.S.O., M.M. Hassanane, E.S. Ahmed and K.H. El-Kholy, 2009. Effect of early-age acclimation on some physiological,immunological responses and chromosomal aberrations in muscovy ducks during exposure to heat stress. Global J. Biotech. and Biochem., 4: 152-159.

Ewing SA, Donald C, Lay J, Von Borrel E. 1999. Farm animal wellbeing: stress physiology, animal behavior and environmental design. Upper Saddle River (New Jersey): Prentice Hall

Hadi, B. R. 2016. Pengaruh Kepadatan Kandang dan Level Protein Ransum Terhadap Karkas, Lemak Abdomen, Hati, Jantung, dan Ventrikulus Itik Kamang Jantan Periode Starter. Skripsi. Fakultas Peternakan Universitas Andalas. Padang

Ismoyowati. 2008. Kajian deteksi produksi telur itik tegal melalui polimerfis meprotein darah. Animal production.Mei 2008. Jlm 122-128. ISSN 14112027. Vol. 10 No 2. Fakultas Peternakan, Universitas Jendral Soedirman.Powekerto.

Ketaren PP. 2002.Kebutuhan gizi itik petelur dan itik pedaging. Bogor (Indonesia): Balai Penelitian Ternak.

Lubis, G. Y. 2017. Pengaruh Pemberian Kulit Ubi Kayu Fermentasi (KUKAF) dengan Bacillus amyloliquefaciens Dalam Ransum Terhadap Bobot Hidup, Persentase Karkas, dan IOFC Pada Itik Pitalah Periode Starter. Skripsi. Fakultas Peternakan Universitas Andalas. Padang.

Mide, Z. M. 2007. Konversi ransum dan income over feed and chick cost yang diberikan ransum mengandung berbagai level tepung rimpang temulawak (Curcuma xanthorriza Roxb). Skripsi Jurusan Makanan Ternak, Fakultas Peternakan. Universitas Hasanuddin, Makasar. 
Musyaffa, F. A. 2019. Pengaruh Suplementasi Tepung Temulawak(Curcuma xanthoriza Roxb) dan Mineral Zink Dalam Ransum Terhadap Persentase Karkas, Lemak Abdomen, Serta Bobot Organ Fisiologi Itik Sikumbang Janti yang Mengalami Cekaman Panas.

PT. Charoen Pokphand Jaya Farm Indonesia. 2013. Kandungan Nutrisi Ransum. Label Ransum. PT.Charoen Pokphand Jaya Farm Indonesia. Lampung..

Rasyaf. 2004. Seputar Makanan Ayam Kampung, Cetakan ke delapan. Penerbit Kanisuis. Yogyakarta

Riani, V. F. 2017. Pengaruh Frekuensi Pemberian Ransum Secara Periodik dan Level Protein Terhadap Laku Pertumbuhan, Intake Protein, dan Income Over Feed Cost Itik Sikumbang Janti. Skripsi. Fakultas Peternakan Universitas Andalas. Padang.

Ricardo, A. Y. 2016. Gambaran Bobot Hidup, Karkas, Persentase Karkas dan Lemak Abdomen Jenis Itik Lokal Di Pembibitan "ER" Payobasung Payakumbuh. Skripsi. Fakultas Peternakan Universitas Andalas. Padang.

Simamora, N. 2011. Performa produksi dan karakteristik organ dalam ayam kampung umur 12-16 minggu yang diinfeksi cacing Ascaridia galli dan disuplementasi ekstrak daun jarak pagar (Jatropha curcas Linn). Skripsi. Institut Pertanian Bogor, Bogor.

Soeparno. 2005. Ilmu dan Teknologi Daging. Universitas Gajah Mada Press, Yogyakarta.

Soeharno, B dan Khairul A. 2014. Panduan Beternak Itik Secara intensif. Penebar Swadaya, Jakarta

Srigandono, B. 2000. Beternak Itik Pedaging. Trubus Agriwidya.Jakarta.

Sturkie, P.D. 2000. Avian Phisiology. 3nd Ed. Springler Verlag, New York.

Subekti, E dan Hastuti, 2015. Pengaruh Penambahan Probiotik Herbal Pada Ransum itik Pedanging.Program Studi Agribisnis Universitas Wahid Hasyim. Semarang

Sudaro, Y dan A. Siriwa. 2000. Ransum Ayam dan Itik. Penebar Swadaya, Jakarta.Rasyaf, M. 1993.Mengelola Itik Komersial. Kanisius,Yogyakarta

Suparyanto, A. 2005. Peningkatan produktivitas dagong itik mandalung melalui pembetukan galur induk. Disertasi Sekolah Pascasarjana, Institut Pertanian Bogor. Bogor

Tamzil, M.H., 2014. Stress Panas pada Unggas: Metabolisme, Akibat dan Upaya Penanggulangannya. , 24(2), pp.57-66. 